\title{
Cytotoxic activity of crude extracts of Dendrobium amoenum and detection of bioactive compounds by GC-MS
}

\author{
Mukti Ram Paudel and Bijaya Pant* \\ Central Department of Botany, Tribhuvan University, Kirtipur, Kathmandu, Nepal
}

\begin{abstract}
Dendrobium amoenum is an epiphytic orchid used as tonic because it has many derivatives of phenols. The crude extract of this orchid has been shown to have antioxidant activity. The objectives of this research are to explore the cytotoxic activity of antioxidantrich crude extract against the human cervical carcinoma and glioblastoma cell lines by MTT assay and to detect the compounds by GC-MS. Methanol (DAM) extract of $D$. amoenum showed high cell growth inhibition percentage against the tested cell lines. DAM extract showed high cytotoxic activity against HeLa cells $\left(\mathrm{IC}_{50}-110.22 \mathrm{\mu g} / \mathrm{ml}\right)$ and least activity against U-251 cells $\left(\mathrm{IC}_{50}-550.55\right.$ $\mu \mathrm{g} / \mathrm{ml}$ ). Thirteen compounds were detected and identified in the extract. Based on abundance, four major compounds detected were: (E)-13-docosenoic acid; oleic acid; 11-octadecenoic acid, methyl ester; and hexadecanoic acid, 2,3-dihydroxypropyl ester. The cytotoxic activity of DAM extract is probably due to the presence of these bioactive compounds, confirmation of which needs further investigation. The result also highlighted the potential of this orchid as the source of natural anticancer drug and to explore their isolation, identification and characterization.
\end{abstract}

Key-words: Dendrobium amoenum, extract, GC-MS, HeLa, MTT, U-251.

\section{Introduction}

Dendrobium is the second largest epiphytic orchid genus in Nepal comprising 30 species, distributed from tropical to temperate climatic regions (Rajbhandari 2014). Most of the Dendrobium species are widely used as traditional medicines (Ng et al. 2012; Xu et al. 2013). Among them, Dendrobium amoenum is mostly used as tonic and also for ornamental purposes (Pant and Raskoti 2013; Rajbhandari 2014). Compounds such as bibenzyl derivatives, phenols, phenanthrenes and sesquiterpenoids have been isolated from this species (Majumder et al. 1999; Majumder and Bandyopadhyay 2010; Venkateswarlu et al. 2002). Due to the presence of such compounds, the crude extract of this orchid has been shown to exhibit antioxidant activity (Paudel et al. 2015).

Elucidating the critical events associated with carcinogenesis provide an opportunity for preventing cancer development by inducing apoptosis, particularly with bioactive agent of traditional medicines (Gali-Muhtasib et al. 2015; Lowe and Lin 2000). Apoptosis induction in cancer cells is initially identified by morphological changes, including cell shrinkage, membrane blebbing, chromatin condensation and nuclear fragmentation. Apoptosis, is therefore, an important defense mechanism against cancer (Lowe and Lin 2000; Elmore 2007). Cervical carcinoma and glioblastoma cell lines were used for the present study. Cervical cancer is common form of cancer in woman's uterus in virtually all developing countries and approximately $12 \%$ of cancers in women are due to cervical cancer (Joshi and Mishra 2013; Sherpa et al. 2015 ). Brain tumors, which account for $2 \%$ of all cancers, are most common childhood tumor after leukemia, constituting approximately $35 \%$ of all childhood malignancies and remain the leading cause of cancer-related deaths in children (Panth 2011). The cytotoxic activity of antioxidant-rich bioactive compounds present in crude extract of this orchid was screened by MTT assay (Mosmann 1983). The objectives of the present research are to explore the cytotoxic activity of crude extract of D. amoenum on human cervical carcinoma and glioblastoma cell lines and to detect the bioactive compounds present in it by GC-MS (Gas Chromatography and Mass Spectrometry). The result of this study may help to explore the pharmacological importance of this orchid in formulation of anticancer drug.

\section{Materials and Method}

\section{PLANT MATERIAL}

Stems of D. amoenum were collected from Daman of Makawanpur district, central Nepal at $1600 \mathrm{~m}$ asl. The plant species was identified with the help of literature and herbarium specimen. The stems were air-dried in the room temperature. 


\section{EXTRACT PREPARATION}

Extract was prepared from the dried stems using soxhlet extractor. Pulverized stem was extracted with hexane, chloroform, acetone, ethanol and methanol successively of their increasing polarity in the ratio of $1: 10(\mathrm{w} / \mathrm{v})$ and extracts were stored at $4^{\circ} \mathrm{C}$ (Mukherjee et al. 2012).

\section{IN VITRO CYTOTOXIC ACTIVITY}

Cytotoxic activity of $D$. amoenum crude extract was determined by using MTT [3-(4,5-dimethylthiazol-2-yl)-2,5diphenyltetrazolium bromide] colorometric assay (Mosmann 1983; Sargent and Taylor 1989). The cytotoxic activities of the extract were determined against human cervical carcinoma and Human gliobastoma cell lines. Human gliobastoma cells (U251) and human cervical carcinoma cells (HeLa) were cultured in RPMI (Roswell Park Memorial Institute) 1640 medium and incubated under $5 \% \mathrm{CO}_{2}$ at $37^{\circ} \mathrm{C}$ for 48 hours to reach $80 \%$ confluence. The cells were harvested by gentle scraping with a cell scraper and resuspended in the medium. From the suspension, $5 \times 10^{3}$ cells in $100 \mu$ medium was dispensed into each well of 96-well cell culture plate and incubated under the same conditions of cell culture for 48 hours to allow adherence and growth of cells. The supernatants were gently aspirated, and $100 \mu \mathrm{l}$ of extracts were added over a range of four cytotoxic concentrations $(100-800 \mu \mathrm{g} / \mathrm{ml})$ prepared in medium and incubated for 24 hours. Ten $\mu 1$ of $5 \mathrm{mg} / \mathrm{ml}$ MTT was added to every well and the plate was re-incubated for further 4 hours. The formazan crystals formed were dissolved in $100 \mu \mathrm{l}$ DMSO (dimethyl sulfoxide). The plate was then read on a microplate reader (iMark ${ }^{\mathrm{TM}}$, Bio-Rad) at $595 \mathrm{~nm}$. The percentage cell growth inhibition was calculated by using following formula:

$\%$ Cell growth inhibition $=100-(A(c s)-A(m)) /(A(c c)-A(m)) \times 100 \%$

where; A(cs) was mean absorbance of treated cells with test samples, A(cc) was mean absorbance of untreated cells, and $\mathrm{A}(\mathrm{m})$ was mean absorbance without cells.

A dose-response curve was plotted for each extract to calculate the inhibition of cell growth by $50 \%\left(\mathrm{IC}_{50}\right) . \mathrm{IC}_{50}$ of extracts was calculated from the regression equation where abscissa represents the series of concentrations of extract and ordinate the triplicate percentage inhibition of cell growth.

\section{GC-MS ANALYSIS}

The analysis of the bioactive chemical constituents of different solvent extracts was done by using GCMS-QP2010 Ultra (Shimadzu Europa GmbH, Germany) with following conditions:

GC condition: column oven temperature $100^{\circ} \mathrm{C}$; injection temperature $280^{\circ} \mathrm{C}$; column flow rate $0.95 \mathrm{ml} / \mathrm{min}$; pre-column pressure $68.3 \mathrm{kPa}$; split ratio of 0 ; high purity helium as the carrier gas.
MS condition: ionization mode EI; ion source temperature $280^{\circ} \mathrm{C}$; interface temperature $280^{\circ} \mathrm{C}$; detector gain mode relative and detector gain $0.91 \mathrm{kV}$; mass-charge ratio $(\mathrm{m} / \mathrm{z})$ 30 to 600 .

Ions detected from the extracts were identified by the molecular formula generated by the use of standards and after through literature search.

\section{STATISTICAL ANALYSIS}

Data are expressed as mean of three analyses. $\mathrm{IC}_{50}$ of extracts for cytotoxic activity was calculated by using appropriate linear/non-linear regression equation fitted on percentage cell growth inhibition activity of each extract at various concentrations with F-statistic at $p \leq 0.05$. All the analyses were done using statistical software R, version 3.1.2 (R core team 2016).

\section{Results}

\section{CRUDE EXTRACT SHOWED IN VITRO CYTOTOXIC ACTIVITY}

The percentage cytotoxic activity of $D$. amoenum is shown in Figure 1 (for HeLa cell line) and Figure 2 (for U-251 cell line). D. amoenum methanol (DAM) extract showed the highest percentage cytotoxic activity against the tested cell lines. The percentage of growth inhibition of extract-treated cells was increased with the increasing concentration of the extract. D. amoenum methanol (DAM) extract showed highest cytotoxic activity against $\mathrm{HeLa}$ cells $\left(\mathrm{IC}_{50}-110.22 \mu \mathrm{g} / \mathrm{ml}\right)$ than other extracts. Similary, D. amoenum ethanol (DAE) extract showed moderate cytotoxic activity against HeLa cells $\left(\mathrm{IC}_{50}\right.$ - $149.14 \mu \mathrm{g} / \mathrm{ml}$; Figure 1). However, D. amoenum methanol (DAM) showed least cytotoxic activity against U-251 cells $\left(\mathrm{IC}_{50}-550.55 \mu \mathrm{g} / \mathrm{ml}\right.$; Figure 2). Besides DAM, other extracts did not show any response against U-251 cells. The addition of extract on the cell lines showed apoptosis of cells. It was seen after the addition of MTT on the extract-treated cells that

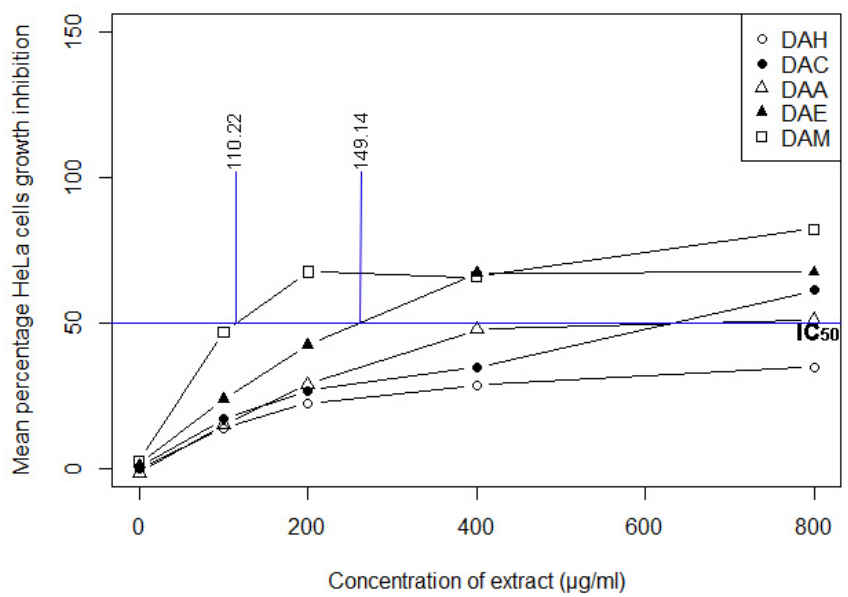

Figure 1. Percentage HeLa cells growth inhibition by crude extracts and their $\mathrm{IC}_{50}(\mathrm{DAH}-D$. amoenum hexane, $\mathrm{DAC}-D$. amoenum chloroform, DAA - D. amoenum acetone, DAE - D. amoenum ethanol, DAM - D. amoenum methanol). 


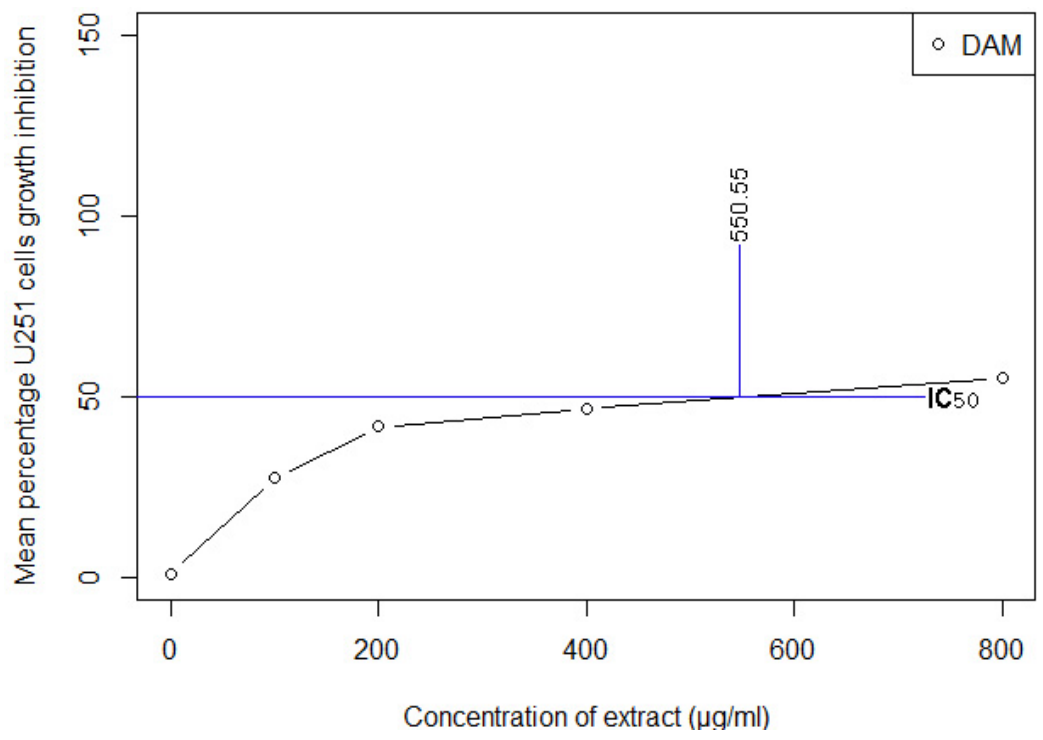

Figure 2. The percentage U-251 cells growth inhibition by DAM extract and its $\mathrm{IC}_{50}(\mathrm{DAM}-\mathrm{D}$. amoenum methanol).

produced the formazan crystals of HeLa cells (Figure 3 ) and U-251 cells (Figure 4).

\section{CHEMICAL CONSTITUENTS WERE DETECTED BY GC-MS}

Thirteen compounds present in DAM were detected using gas chromatography (GC) and identified through mass spectrometry (MS). The detected and identified compounds were listed in Table 1 with their retention time (RT), total content in the crude extract (in percentage) and observed masscharge ratio $(\mathrm{m} / \mathrm{z})$. Based on abundance, four major compounds detected were: (E)-13-docosenoic acid (29.95\%), oleic acid (26.95\%), 11-octadecenoic acid, methyl ester (20.06\%) and hexadecanoic acid, 2,3-dihydroxypropyl ester (10.04\%) (Table 1).

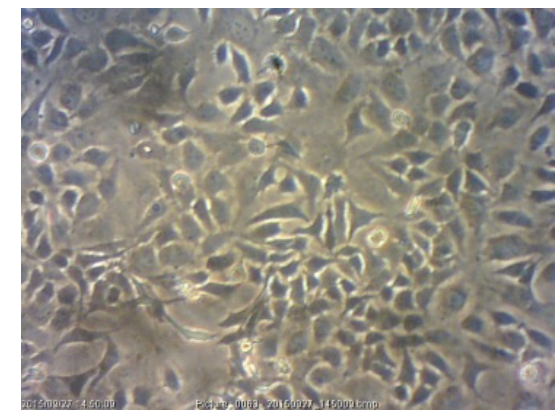

(a)

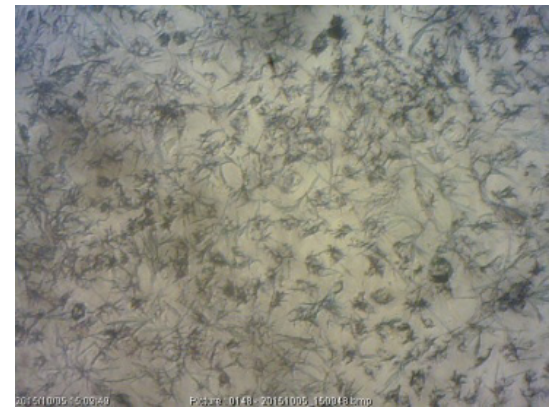

(b)

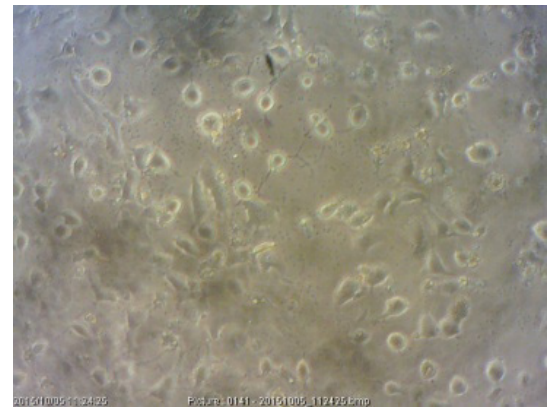

(c)

Figure 3. Apoptosis of HeLa cells after addition of methanol extract $(200 \mu \mathrm{g} / \mathrm{ml})$ : (a) HeLa cells before addition of extract, (b) formazan crystals in cells treated with the extract after addition of MTT, and (c) dead HeLa cells.

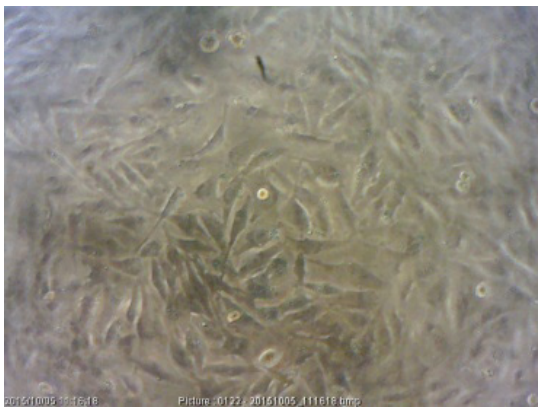

(a)

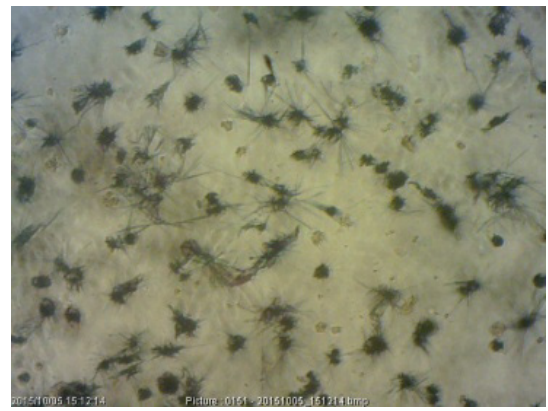

(b)

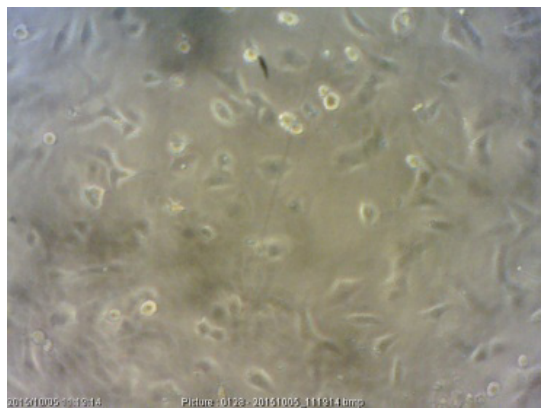

(c)

Figure 4. Apoptosis of U-251 cells after addition of methanol extract $(800 \mu \mathrm{g} / \mathrm{ml})$ : (a) U-251 cells before addition of extract, (b) formazan crystals in cells treated with the extract after addition of MTT, and (c) dead U-251 cells. 
Table 1. Compounds detected and identified by GC-MS analysis of methanol extract (DAM).

\begin{tabular}{clccc}
\hline S.N. & Compound name & RT (min) & Content \% & $\begin{array}{c}\text { Mass-charge } \\
\text { ratio (m/z) }\end{array}$ \\
\hline 1 & (E)- 13-Docosenoic acid & 14.60 & 29.95 & 55.05 \\
2 & Oleic acid & 12.19 & 26.95 & 41.05 \\
3 & 11-Octadecenoic acid, methyl ester & 11.54 & 20.06 & 55.05 \\
4 & Hexadecanoic acid, 2,3-dihydroxypropyl ester & 13.15 & 10.04 & 43.05 \\
5 & n-Hexadecanoic acid & 10.87 & 5.98 & 4.73 \\
6 & 2-Tridecenal, (E)- & 16.87 & 1.48 & 43.05 \\
7 & 9-Octadecenamide, (Z)- & 13.87 & 1.48 & 59.10 \\
8 & Tetradecanoic acid, 12-methyl-, methyl ester & 11.67 & 0.82 & 43.10 \\
9 & Pentadecanoic acid, 14-methyl-, methyl ester & 10.32 & 0.80 & 74.10 \\
10 & 7-Nonenamide & 10.95 & 0.41 & 59.05 \\
11 & Cyclopropanepentanoic acid, 2-undecyl-, methyl ester, trans- & 12.67 & 0.37 & 43.10 \\
12 & Di-alpha.-L-xylofuranose 1,2':2,1'-dianhydride, 4,4',5,5'-tetradeoxy- & 15.16 & 0.37 & 55.10 \\
& 4,4'-bis(methylamino)- & & 17.56 & 0.37 \\
\hline
\end{tabular}

\section{Discussion}

Cytotoxic activity of the crude extract was observed against the cervical carcinoma and glioblastoma cell lines by MTT assay. The cell growth inhibition effect was strengthened with the increase in crude extract concentrations. The susceptibility of cells to the extract exposure was characterized by $\mathrm{IC}_{50}$ values. Considering the $\mathrm{IC}_{50}$ values, the methanol extract has better cytotoxic effect than that of other extract types. This indicates that the methanol extract is more potent on the cell lines used. The antitumor and anticancer activities of crude extracts of Dendrobium were explained in previous studies (Devi et al. 2009; Lam et al. 2015; Shrestha et al. 2015; Sun et al. 2016; Paudel et al. 2017). In our previous study, we quantified the total phenolic and flavonoid contents in the crude extract of D. amoenum (Paudel et al. 2015). In the present study, we further explored and detected 13 compounds from the crude extracts by GC-MS analysis. Compounds, like bibenzyl derivatives, phenols, phenanthrenes and sesquiterpenoids are known to be present in D. amoenum (Majumder et al. 1999; Venkateswarlu et al. 2002; Majumder and Bandyopadhyay 2010). The cytotoxic activity of $D$. amoenum against the cervical carcinoma and gliobalstoma cell lines has been therefore attributed to the bioactive compounds present in the crude extracts of this orchid.

Many chemotherapeutic drugs and folk medicinal plants exert their anticancer effect by inducing cell apoptosis (Chen et al. 2008; Prasad and Koch 2014; Peng et al. 2017). The cervical carcinoma and glioblastoma cells treated with crude extract showed morphological changes, such as reduced size and cell volume, cell shrinkage, membrane blebbing, chromatin condensation, nuclear fragmentation and formation of apoptotic bodies, indicating that the extract induced the apoptosis (Lowe and Lin 2000; Pandey et al. 2011; Kim et al. 2012; Gali-Muhtasib et al. 2015). Studies have shown that phenolic derivatives are responsible for the induction of apoptosis in cancer cells (Prasad and Koch 2014; Chen et al. 2015; Milutinoviæ et al. 2015).

The cytotoxic activity of DAM extract of $D$. amoenum is due to the presence of several bioactive compounds, confirmation of which needs further investigation. The result also highlighted the potential of this orchid as the source of natural anticancer drug and to explore their isolation, identification and characterization.

\section{Acknowledgments}

We are thankful to Department of Neurosurgery of Kagoshima University, Japan for providing U-251 cell lines and Everest Biotech Pvt. Ltd., Nepal for providing HeLa cell lines; and University Grants Commission (UGC), Nepal for financial support. We thank Dr. Suresh Kumar Ghimire for his critical review, language editing and suggestion in the earlier version of the manuscript.

\section{References}

Chen M., Meng H., Zhao Y., Chen F. and Yu S. 2015. Antioxidant and in vitro anticancer activities of phenolics isolated from sugar beet molasses. BMC Complementary and Alternative Medicine, 15: 313

Chen Y., Li Y., Qing C., Zhang Y., Wang L. and Liu Y. 2008. 1,4,5-Trihydroxy-7-methoxy-9H-fluoren-9-one, a new cytotoxic compound from Dendrobium chrysotoxum. Food Chemistry, 108: 973-976.

Devi P.U., Selvi S., Devipriya D., Murugan S. and Suja S. 2009. Antitumor and antimicrobial activities and inhibition of in-vitro lipid peroxidation by Dendrobium nobile. African Journal of Biotechnology, 8: 2289-2293. 
Elmore S. 2007. Apoptosis: A review of programmed cell death. Toxicologic Pathology, 35: 495-516.

Gali-Muhtasib H., Hmadi R., Kareh M., Tohme R. and Darwiche N. 2015. Cell death mechanisms of plant-derived anticancer drugs: beyond apoptosis. Apoptosis, 20: 1531-1562.

Joshi M. and Mishra S.R. 2013. Cancer screening in Nepal. Health Prospect: Journal of Public Health, 12: 18-20.

Kim H., Kim H., Mosaddik A., Gyawali R., Ahn K.S. and Cho S.K. 2012. Induction of apoptosis by ethanolic extract of mango peel and comparative analysis of the chemical constitutes of mango peel and flesh. Food Chemistry, 133: 416-422.

Lam Y., Ng T.B., Yao R.M., Shi J., Xu K., Sze S.C.W. and Zhang K.Y. 2015. Evaluation of chemical constituents and important mechanism of pharmacological biology in Dendrobium plants. Evidence-based Complementary and Alternative Medicine, 2015: 25 .

Lowe S.W. and Lin A.W. 2000. Apoptosis in cancer. Carcinogenesis, 21: 485-495.

Majumder P.L. and Bandyopadhyay S. 2010. Stilbenoids and sesquiterpene derivatives of the orchids Gastrochilum calcoelaria and Dendrobium amoenum: Application of 2D NMR spectroscopy in structural elucidation of complex natural products. Journal of the Indian Chemical Society, 87: 221-234.

Majumder P.L., Guha S. and Sen S. 1999. Bibenzyl derivatives from the orchid Dendrobium amoenum. Phytochemistry, 52: 1365-1369.

Milutinović M.G., Stanković M.S., Cvetković D.M., Topuzović M.D., Mihailović V.B. and Marković S.D. 2015. Antioxidant and anticancer properties of leaves and seed cones from European yew (Taxus baccata L.). Archives of Biological Sciences, 67: 525-534.

Mosmann T. 1983. Rapid colorimetric assay for cellular growth and survival: application to proliferation and cytotoxicity assays. Journal of Immunological Methods, 65: 55-63.

Mukherjee S., Pathak D., Parikh J., Jagtap S., Shaikh S. and Tupe R. 2012. Antiglycation and antioxidant activity of a rare medicinal orchid Dendrobium aqueum Lindl. Medicinal Chemistry and Drug Discovery, 2: 17-29.

Ng T.B., Liu J., Wong J.H., Ye X., Wing Sze S.C., Tong Y. and Zhang K.Y. 2012. Review of research on Dendrobium, a prized folk medicine. Applied Microbiology and Biotechnology, 93: 1795-1803.

Pandey S., Chatterjee S.J., Ovadje P., Mousa M. and Hamm C. 2011. The efficacy of dandelion root extract in inducing apoptosis in drug-resistant human melanoma cells. Evidence-based Complementary and Alternative Medicine, 2011: 11.

Pant B. and Raskoti B.B. 2013. Medicinal Orchids of Nepal. Himalayan Map House Pvt. Ltd., Kathmandu, Nepal.
Panth R. 2011. A systematic approach to cytological evaluation of central nervous system tumours. Journal of Pathology of Nepal, 1: 136-141.

Paudel M.R., Chand M.B., Karki N. and Pant B. 2015. Antioxidant activity and total phenolic and flavonoid contents of Dendrobium amoenum Wall. ex Lindl. Botanica Orientalis: Journal of Plant Science, 9: 20-26.

Paudel M.R., Chand M.B., Pant B. and Pant B. 2017. Cytotoxic activity of antioxidant-riched Dendrobium longicornu. Pharmacognosy Journal, 9: 499-503.

Peng C., QiX.M., MiaoL.L. and Ren J.2017. 1,2:5,6-dianhydrogalactitol inhibits human glioma cell growth in vivo and in vitro by arresting the cell cycle at G2/M phase. Acta Pharmacologica Sinica, 38: $1-10$.

Prasad R. and Koch B. 2014. Antitumor activity of ethanolic extract of Dendrobium formosum in T-cell lymphoma: An in vitro and in vivo study. BioMed Research International, 2014: 1-11.

R core team 2016. R: A Language and Environment for Statistical Computing. R Foundation for Statistical Computing, Vienna, Austria.

Rajbhandari K.R. 2014. Orchids of Nepal: Status, Threat and Conservation, In: Proceedings of National Workshop on NTFP/ MAPs Sector Action Plan Development: Orchid, pp. 1-40. Department of Plant Resources, Ministry of Forest and Soil Conservation and Central Department of Botany, Tribhuvan University, Kathmandu, Nepal.

Sargent J.M. and Taylor C.G. 1989. Appraisal of the MTT assay as a rapid test of chemosensitivity in acute myeloid leukaemia. British Journal of Cancer, 60: 206-210.

Sherpa A.T., Karki B.S., Sundby J., Nygard M., Franceschii S. and Clifford G. 2015. Population based study of cervical cancer screening in Bharatpur, Nepal. Journal of Manmohan Memorial Institute of Health Sciences, 1: 3-8.

Shrestha P., Bista M., Sharma P., Shrestha S., Lamichhane B., Adhikari S., Pandey B.R. and Shrestha B.G. 2015. Phytochemical screening, antimicrobial activity and cytotoxicity of Nepalese medicinal plants Swertia chirayita and Dendrobium amoenum. Nepal Journal of Biotechnology, 3: 48-54.

Sun J., Guo Y., Fu X., Wang Y., Liu Y., Huo B., Sheng J. and Hu X. 2016. Dendrobium candidum inhibits MCF-7 cells proliferation by inducing cell cycle arrest at G2/M phase and regulating key biomarkers. OncoTargets and Therapy, 9: 21-30.

Venkateswarlu S., Raju M.S.S. and Subbaraju G.V. 2002. Synthesis and biological activity of isoamoenylin, a metabolite of Dendrobium amoenum. Bioscience, Biotechnology and Biochemistry, 66: 2236-2238.

Xu J., Han Q.B., Li S.L., Chen X.J., Wang X.N., Zhao Z.Z. and Chen H.B. 2013. Chemistry, bioactivity and quality control of Dendrobium, a commonly used tonic herb in traditional Chinese medicine. Phytochemistry Reviews, 12: 341-367. 